Proceedings

\title{
Evaluating the Capacity of Several Antioxidants to Attenuate the Renal Toxicity Induced by Methotrexate Therapy +
}

\author{
Miruna S. Stan * and Anca Dinischiotu \\ Department of Biochemistry and Molecular Biology, University of Bucharest, Faculty of Biology, Bucharest, \\ Romania; anca.dinischiotu@bio.unibuc.ro \\ * Correspondence: miruna.stan@bio.unibuc.ro; Tel.: +40-21-3181575 \\ + Presented at the 1st International e-Conference on Antioxidants in Health and Disease, 1-15 December \\ 2020; Available online: https://cahd2020.sciforum.net/.
}

Published: 30 November 2020

\begin{abstract}
Methotrexate (MTX) chemotherapy is often limited by its severe side effects which include nephrotoxicity. In the continuous search of efficient antioxidants that could ameliorate this toxic condition of MTX, our study aimed to evaluate the efficiency of N-acetyl cysteine (NAC), Trolox methyl ether (Trolox-Me), and curcumin as potent antioxidants using an in vitro model of MTXinduced toxicity. Human embryonic kidney (HEK293) cells were pre-exposed to different antioxidants for $2 \mathrm{~h}$ prior to MTX $(5 \mu \mathrm{M}$ and $50 \mu \mathrm{M})$. After $24 \mathrm{~h}$ of exposure to MTX, the cell viability and morphology were assessed, activities of antioxidant enzymes and levels of lipid peroxidation were measured by spectrophotometrically methods, and protein expression was determined by Western blotting. Exposure to MTX at concentrations between 1 and $100 \mu \mathrm{M}$ for $24 \mathrm{~h}$ decreased cell viability in a dose-dependent manner and was correlated with the increase of p53 protein expression. All three antioxidants tested have proved that can inhibit the apoptosis induced by MTX, as revealed by the expression of heat shock proteins (Hsp27, Hsp60, Hsp70 and Hsp90). Pretreatment of cells with $50 \mu \mathrm{M}$ of Trolox-Me succeeded to significantly decrease the MTX-induced cell death. The reduction in the activities of glutathione reductase and glutathione S-transferase after MTX incubation was correlated with a low level of GSH, and was attenuated by the pre-incubation with Trolox-Me or curcumin, these antioxidants being able to maintain enough GSH for the reactions of conjugation with MTX metabolites in order to decrease its toxicity. In conclusion, the pre-treatment with curcumin, Trolox-Me or NAC proved extremely effective at blocking MTX toxicity at the concentration investigated in vitro on kidney cells. The results of our study encourage further clinical assessments in order to use these antioxidants in dietary prevention of renal side effect of MTX.
\end{abstract}

Keywords: methotrexate; HEK cells; antioxidants; nephrotoxicity

\section{Introduction}

Methotrexate (MTX), a classical antifolate used in chemotherapy, induces renal dysfunction after high-dose therapy. The present study was designed to investigate the nephroprotective properties of $\mathrm{N}$-acetyl cysteine (NAC), Trolox methyl ether (Trolox-Me) and curcumin, as potent antioxidant compounds, against MTX-induced toxicity in human kidney (HEK293) cells. 
The 1st International Electronic Conference on Antioxidants in Health and Disease, 1-15 December 2020

\section{Experiments}

HEK293 cells were pre-incubated in cell culture media supplemented with different antioxidants for $2 \mathrm{~h}$ prior to MTX addition for $24 \mathrm{~h}$. Cell viability was assessed by MTT test under control, MTX and antioxidant exposed conditions. In order to establish antioxidant efficiency, several indices of oxidative stress were measured: glutathione reductase (GRed) and glutathione S-transferase (GST) activities, and the level of malondialdehyde (MDA). Heat shock protein and p53 expressions were assessed by Western blotting.

\section{Results}

Exposure to MTX (5 $\mu \mathrm{M}$ and $50 \mu \mathrm{M})$ for $24 \mathrm{~h}$ decreased cell viability in a dose-dependent manner. Pre-treatment with N-acetyl cysteine $(10 \mathrm{mM})$, curcumin $(2.5 \mu \mathrm{M}$ and $5 \mu \mathrm{M})$ and Trolox methyl ether $(100 \mu \mathrm{M})$ restored the cell proliferation at control values (Figure 1$)$. The MTX-induced oxidative stress was proved by increased lipid peroxidation and reduction in antioxidant enzymatic defense capacity of GRed and GST. Moreover, MTX activates p53 and Hsp70 expression, and downregulates Hsp60 and Hsp90 protein levels. Cytotoxic effects of $5 \mu \mathrm{M}$ MTX were greatly reduced in the presence of NAC or Trolox or Curcumin which replenished the antioxidant status and provided a protective and adaptive response to cellular stress induced by MTX.
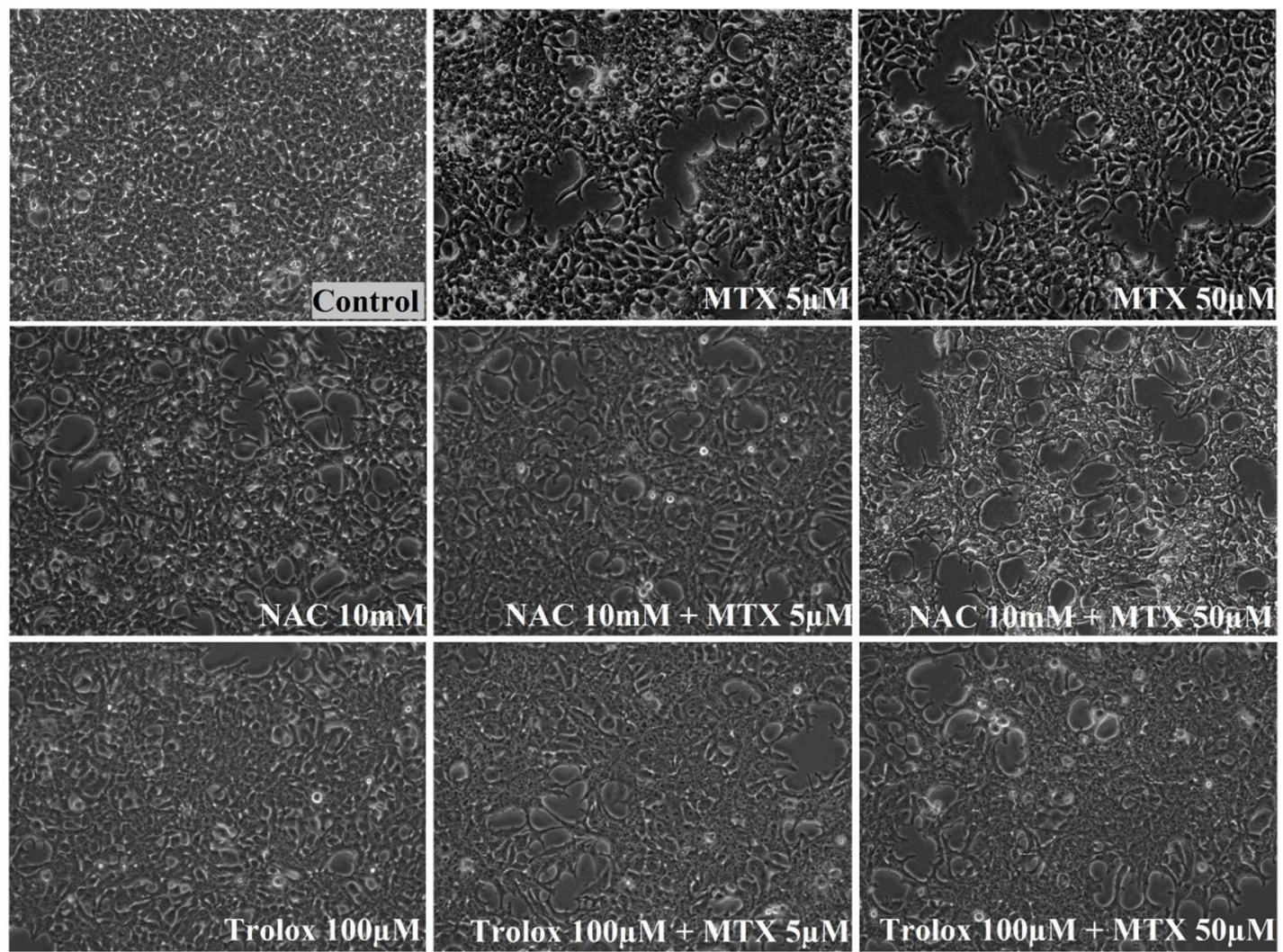

(a)
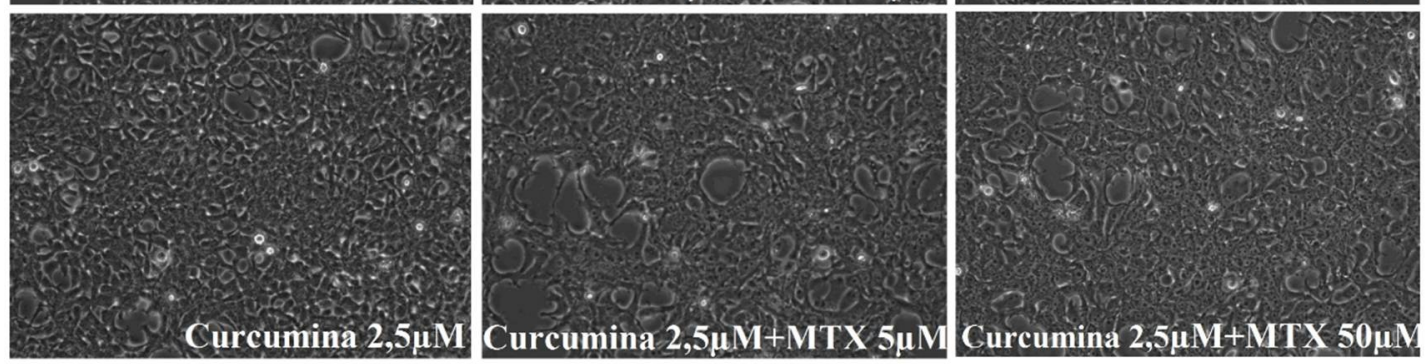
The 1st International Electronic Conference on Antioxidants in Health and Disease, 1-15 December 2020
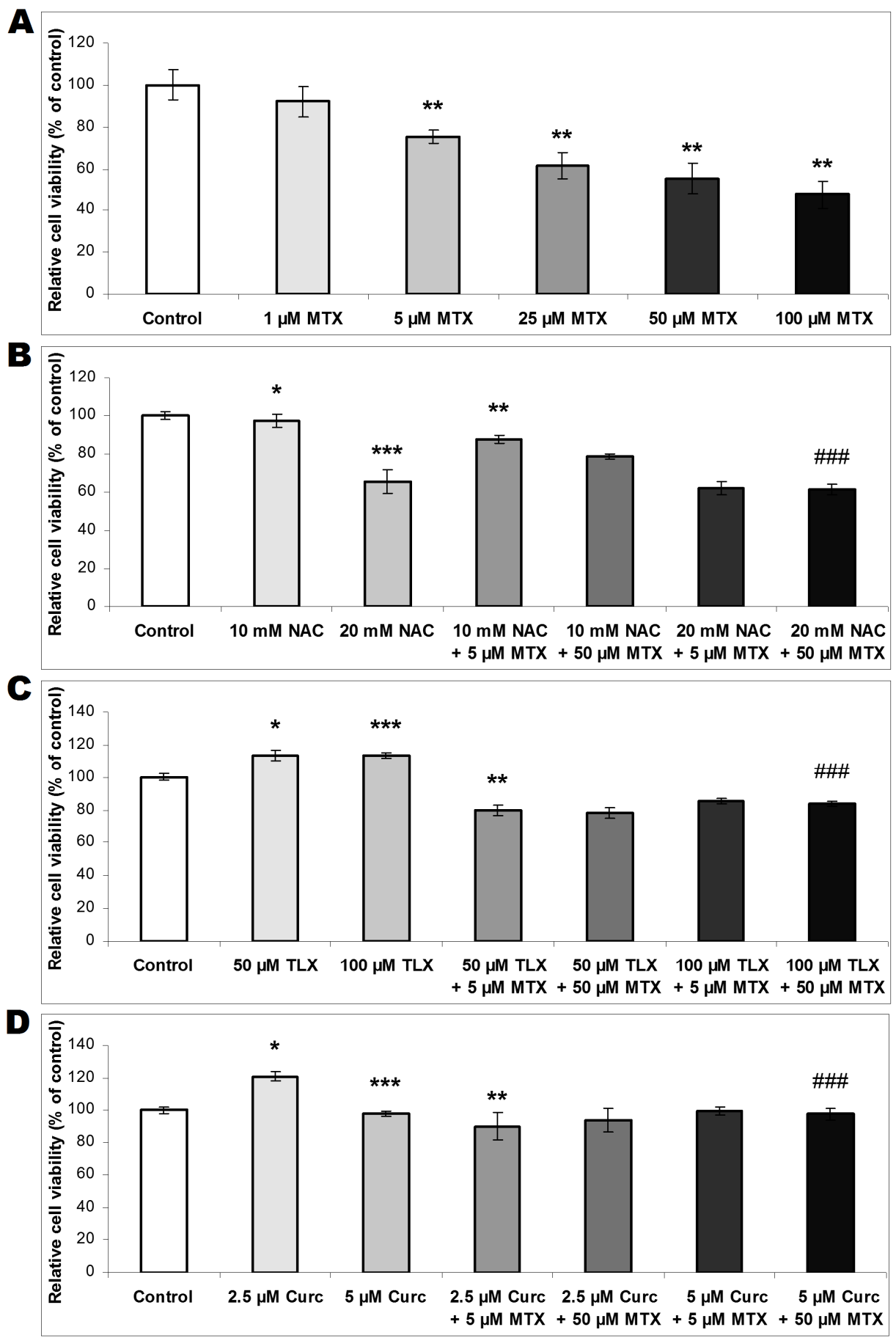

(b)

Figure 1. Cell viability after exposure to methotrexate (MTX) and antioxidants (NAC-N-acetyl cysteine; TLX-Trolox, and Curc-curcumin), as observed by optic miscropy (a) and measured by MTT assay (b). Results were calculated as means \pm standard deviations $(\mathrm{n}=3)$ and expressed relative to control. ${ }^{*} p<0.05,{ }^{* *} p<0.01$ and ${ }^{* * *} p<0.001$ compared to control; \#\#\#p $p .001$ compared to MTX exposure only.

\section{Conclusions}

Antioxidant pre-treatment proved extremely effective at blocking MTX toxicity at the doses tested on cultured HEK cells and should be consider for further adjuvant therapies in alleviating the renal side effect of MTX. 
The 1st International Electronic Conference on Antioxidants in Health and Disease, 1-15 December 2020

Author Contributions: M.S.S. and A.D. conceived and designed the experiments, performed the experiments, analyzed the data and wrote the paper. All authors have read and agreed to the published version of the manuscript.

Acknowledgments: This work was supported by UEFISCDI through the project PN-III-P2-2.1-PED2019-1471 "Noi produsi biocompatibili de tip shagaol si curcuminoidic utilizati drept adjuvanti in radioterapia cancerului".

Conflicts of Interest: The authors declare no conflict of interest. The founding sponsors had no role in the design of the study; in the collection, analyses, or interpretation of data; in the writing of the manuscript, and in the decision to publish the results.

Publisher's Note: MDPI stays neutral with regard to jurisdictional claims in published maps and institutional affiliations.

(C) 2020 by the authors; licensee MDPI, Basel, Switzerland. This article is an open access article distributed under the terms and conditions of the Creative Commons by Attribution (CC-BY) license (http://creativecommons.org/licenses/by/4.0/). 